\title{
Pre- and post-weaning growth of beef calves reared by cows on one of five lifetime nutrition levels
}

\author{
D.C. SMEATON, J.B. CLAYTON and A. MALTHUS \\ Whatawhata Research Centre, Private Bag 3089, Hamilton
}

\section{Abstract}

The hypothesis that currently recommended liveweights for beef cows are too high was tested at Whatawhata Research Centre. Industry claims have been that high levels of reproductive efficiency can be achieved with cows running up to $20 \%$ lighter than current targets, and eating proportionately less pasture. We ran 150 Hereford $x$ Friesian cows on 1 of 5 lifetime feeding levels or treatments. Average liveweights of the five treatments ranged from 470 to $390 \mathrm{~kg}$ at mating but pregnancy rate was not affected. Calf weaning weight was affected, however $(\mathrm{P}<0.001)$, especially of the calves from the lowest cow treatment. Hence, although these light cows were eating less than their heavy contemporaries, in practice,. farmers might be reluctant to run them unless their light calves were able to compensate before slaughter. The objective of this trial was to determine the degree of compensatory growth by the lighter calf treatments. The impacts of meal supplementation at weaning, and weaning date, were also tested. The calves were weaned in either mid-February or mid-March and half of them were supplemented with meal for 5 weeks. A major finding, confirming earlier research, was that rearing effects in early life are not readily compensated for later. Calves weaned from the lightest cow treatment had shown no compensation $(\mathrm{P}<0.001)$ up to 6 weeks after being run to\&her with their heavier contemporaries. Meal supplementation gave a substantial improvement iii liveweight $(+19 \mathrm{~kg}, \mathrm{P}<0.01)$ in the calves weaned early onto poor quality summer pasture. However, 10 weeks after supplementation ceased, this benefit was reduced to $2.4 \mathrm{~kg}$. In the late-weaned calves, supplementation resulted in a $10 \mathrm{~kg}$ advantage, which, unlike the above, was retained 6 weeks later $(P<0.05)$. Late weaning was almost as effective as meal feeding the early-weaned calves. At 10 weeks after late weaning, the lateweaned calves were still $16 \mathrm{~kg}$ heavier $(\mathrm{P}<0.01)$ than their early-weaned contemporaries. These results suggest, firstly, that cow lifetime nutrition, below a threshold level may permanently affect calf liveweight; secondly, the benefits of meal supplementation at weaning may not be permanent or economic, thirdly, weaning early, particularly in a dry season is not recommended.

Keywords: beef calves, compensatory growth, cow nutrition, meal, weaning date

\section{Introduction}

A major reason for running beef cows on hill country is their flexible feed demand in the face of a seasonal pasture growth curve (McCall 1994; Pleasants et al. 1994). Furthermore, they fit in well with other stock classes such as sheep or finishing stock because of their ability to assist in the management of feed quality (Pleasants et al. 1991). These attributes are obvious in the spring when pasture is growing rapidly. While the cow is lactating, her intake doubles at least (Smeaton et al. 1979). Then, during summer and early autumn she still supports good calf growth rates even though other stock, perform poorly at this time (McCall 1994). Subsequently in late autumn and winter she can sustain a period of below maintenance intake by losing a substantial amount of weight provided her body condition is adequate to start with.

To assist farmers to use the cow as above, target liveweight and feeding guidelines have been published (Smeaton et al. 1979; NZ Beef Council circa 1990). However, some members of the beef industry claim that these targets are more generous than necessary and that high levels of reproductive efficiency and calf weaning weights can be obtained off cows running up to $20 \%$ lighter.

These claims were tested in a 4-year study at Whatawhata Research Centre. Beef cows were run at 1 of $\mathbf{5}$ lifetime feeding levels (treatments) to generate 1 of 5 cow liveweight profiles (Table 1).

\section{Table 1 Effects of lifetime nutrition on cow liveweight.}

\begin{tabular}{lcccccc}
\hline & \multicolumn{3}{c}{$\begin{array}{c}\text { Cow lifetime nutrition treatment } \\
\text { High }\end{array}$} & $\begin{array}{c}\text { or liveweight profile } \\
\text { L ow }\end{array}$ & $\begin{array}{c}\text { Typical } \\
\text { target }\end{array}$ \\
\hline Time & 1 & 2 & 3 & 4 & 5 & (2) \\
\hline Post-calving & 426 & 307 & 370 & 367 & 356 & 410 \\
Start-mate & 472 & 446 & 423 & 415 & 390 & 450 \\
Weaning & 485 & 469 & 414 & 420 & 408 & 440 \\
\hline
\end{tabular}


The major treatment effect was on calf weaning weight, with reproductive efficiency of the cows hardly affected (Smeaton, unpublished). At weaning time, the lightest treatment cows were $17 \%$ lighter on average than the heaviest treatment (Table 1). Measurements of intake (Smeaton et al. 1995) indicated they had eaten up to $15 \%$ less. Their calves were $10-12 \%$ lighter. However, although these light cows appear to have been more efficient, farmers could still be very reluctant to run them unless the light calves were able to compensate later. Our objective was to measure compensation by these calves after weaning and to determine any potential benefits of weaning the calves earlier along with meal supplementation.

\section{Materials and methods}

The present trial was carried out on the 1994-born crop of calves from the above trial. The 138 calves were all suckled by Hereford $\times$ Friesian cows running at one of the five lifetime nutrition levels described above.

The five cow nutrition treatments were set such that the heaviest treatment cows were at least $70 \mathrm{~kg}$ heavier on average than the lightest treatment. The treatments were also set so as to be above and below currently recommended target weights (Table 1).

The calf trial was conducted in 2 parts:

Part 1: All the calves from the treatment 1 and 5 cows above and $25 \%$ of the treatment 2, 3 and 4 cows, were weaned "late" (15 March 1995). From this time on, they ran together on pasture.

Part 2: Calves from the treatment 2, 3 and 4 cows above were weaned either "early" (E) on 8 February 1995 or "late" (L) on 15 March 1995. In addition, the calves at each weaning time were either given ad lib. meal supplement $(+\mathrm{M})$ or not $(-\mathrm{M})$. In other words, Part 2 was a $3 \times 2 \times 2$ factorial design with 3 cow nutrition treatments $\times 2$ weaning dates $\times 2$ meal levels (nil or ad lib.). The meal used was a suitable calf meal currently commercially available ("Grow-up") and was supplied by NRM Feeds (NZ) Ltd. The meal was a composite product with a cereal base, containing $18 \%$ crude protein (DM basis) and $11.5 \mathrm{MJ} \mathrm{ME} / \mathrm{kg} \mathrm{DM}$. At each weaning time, all weaned calves were also given ad lib. pasture (Table 2). The unweaned calves remained on their mothers with their lifetime nutrition treatments. The $\mathrm{L}-\mathrm{M}$ calves were also used in the Part 1 analyses as described in Part 1 above. Pasture allowance and pasture quality were estimated using techniques involving visual assessment and pasture cuts as described by Smeaton et al. 1983 .

Calves were weighed approximately fortnightly. Statistical analyses were carried out on calf weights using covariance analyses and adjusting for calf sex. Calf birth date was fitted as a covariate after it was found to not be affected by cow lifetime nutrition level. Calf birth weight was affected $(\mathrm{P}<0.05)$ by cow treatment and so it was not used as a covariate in the Part 1 analyses. In the Part 2 analyses, liveweight at early weaning (8 February) was used as a covariate.

\section{Results and Discussion}

Part 1: Cow lifetime nutrition treatment substantially affected calf liveweight at all stages $(\mathrm{P}<0.001$; at birth $\mathrm{P}<0.05$ ) (Figure 1).

The biggest effect of cow treatment on calf weight occurred in those calves reared by the treatment 5 cows (lightest treatment), with all the other treatment averages

Figure 1 Effects of cow treatment on calf liveweight.

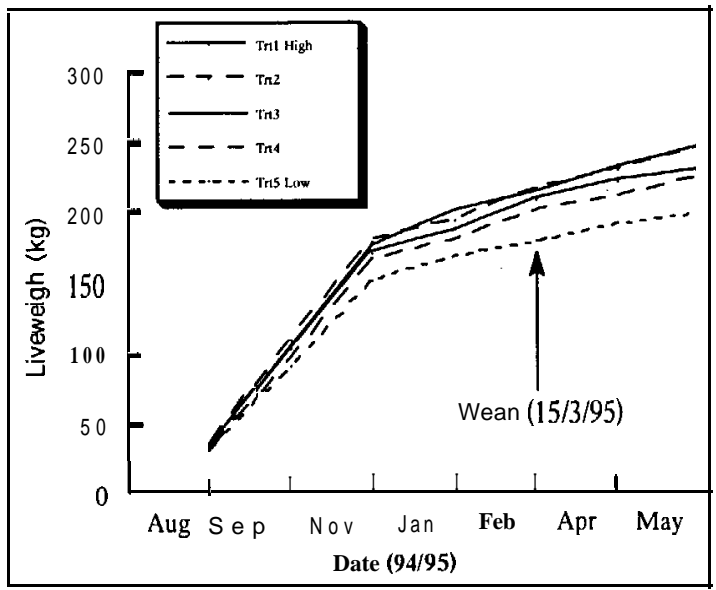


being within $\pm 5 \%$ of the treatment 1 calves. By the end of May 1995, 10 weeks after weaning, compensation by the lighter groups was negligible. This finding is very similar to those described by Berge (1991) and Everitt et al. (1975) who found that compensatory growth, even 1 year later, did not occur in steers poorly reared up to 16 weeks of age.

Part 2: Meal supplementation benefited calf liveweight $(\mathrm{P}<0.001)$ especially in the $\mathrm{E}+\mathrm{M}$ group (Figure 2 ). Both $\mathrm{E}+\mathrm{M}$ and $\mathrm{L}+\mathrm{M}$ groups grew at similar rates during their supplementation periods but the E -M calves hardly grew at all during this time. Pasture quality as affected by rainfall (or lack of) may have contributed to this result (Table 2). The late-weaned calves were weaned onto higher quality pasture than the early weaned calves and were able to gain some weight even without meal (Figure 2).

Figure 2 Effects of weaning date and meal supplement on calf liveweight.

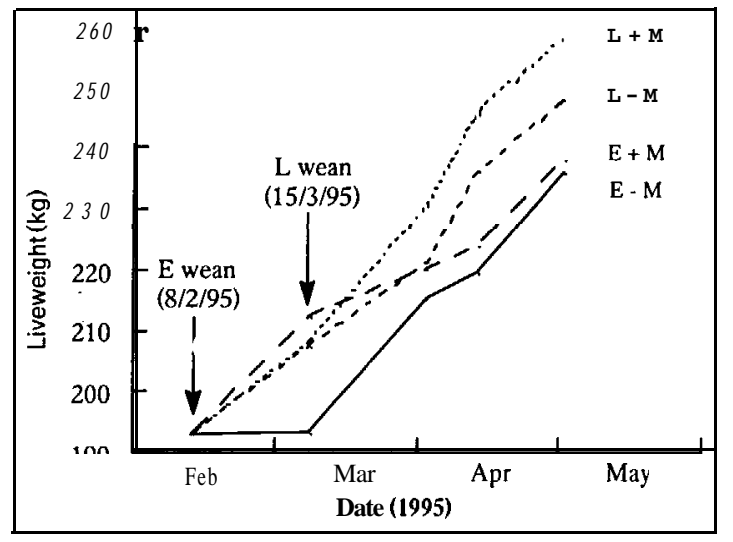

The E-M calves showed considerable compensation to the end of April and by the end of May were similar in weight to the $\mathrm{E}+\mathrm{M}$ calves. This is common in older animals differentially fed for short periods (Nicol \& Kitessa 1995). Of some surprise therefore, is the lack of compensation in the $\mathrm{L}-\mathbf{M}$ calves to the end of May (interaction NS). Further weighings are required to determine if their $11 \mathrm{~kg}$ disadvantage compared with the $\mathrm{L}+\mathrm{M}$ calves is permanent. Again, however, this result is not inconsistent with the variable nature of compensatory growth in cattle (Nicol \& Kitessa 1995).

In both the $\mathrm{E}+\mathrm{M}$ and the $\mathrm{L}+\mathrm{M}$ groups, $60-70 \mathrm{~kg}$ of meal per calf was fed during supplementation. About $90 \%$ of this was consumed. The retail cost of the meal was \$35-\$40 excluding GST per calf. At a schedule value of $\$ 2 / \mathrm{kg}$ carcass weight, a break-even liveweight improvement of over $30 \mathrm{~kg}$ is required. Clearly this was not achieved in this study.

Figure 2 also demonstrates that early weaning is likely to be detrimental to calf liveweight. The lateweaned calves (while still on their mothers) grew almost as well as the $\mathrm{E}+\mathrm{M}$ calves. The benefits of late weaning appeared to be permanent, at least until the end of May when the late-weaned calves were still $15.8 \mathrm{~kg}$ heavier $(\mathrm{P}<0.001)$ than the early-weaned calves. In terms of cow liveweight, there was no cost in achieving this. At early weaning, the early-weaned cows at $434 \mathrm{~kg}$ were 9 $\mathrm{kg}$ lighter than the late-weaned cows. This nonsignificant difference still applied at late weaning. These findings are at variance with those of McCall et al. (1988) who, even so, concluded that the benefits of late weaning outweighed any costs of cow liveweight loss and reduced the demand for quality autumn pasture.

\section{Conclusions}

1. The major result of this experiment was that cow lifetime nutrition treatment or liveweight profile affected calf weight from birth onwards and these affects appeared to be permanent. However, the effect occurred only when cows were run below a threshold liveweight profile about 5-10\% below currently recommended targets.

2. Meal supplementation resulted in significantly improved liveweight gain in weaned calves with the benefits greatest in calves weaned onto poor (summer dry) pastures. These benefits appeared not to be permanent and were unlikely to be economic especially in light of 3 ) below.

3. Late-weaned calves showed superior liveweight gain than those weaned early, even 6 weeks after late weaning had occurred.

\section{ACKNOWLEDGEMENTS}

The authors wish to thank NRM Feeds (NZ) Ltd for their supply of meal for this experiment. Thanks are also extended to Dr Martin Upsdell for statistical analyses and to colleagues for manuscript comments and suggestions.

\section{REFERENCES}

Berge, P. 1991. Long-term effects of feeding during calfhood on subsequent performance in beef cattle (a review). Livestock production science 28: 170201.

Everitt, G.C.; Jury, K.E.; Ward, J.D.B. 1975. Growth rates of Friesian $x$ Friesian, Hereford $x$ Friesian and Simmental $\times$ Friesian steers in several environments. 
Proceedings of the New Zealand Society of Animal Production 35: 119-l 28.

McCall, D.G. 1994. The complimentary contribution of the beef cow to other livestock enterprises. Proceedings of the New Zealand Society of Animal Production 54: 323-327.

McCall, D.G.; Scott, M.L.; Dow, B.W. 1988. Calf weaning and summer grazing strategies for efficient beef cow use on hill country. Proceedings of the New Zealand Society of Animal Production 48: 237242.

New Zealand Beef Council circa 1990. Beef cow management. A publicity sheet with recommended weights and feeding levels for beef cows. Source New Zealand Beef Council Inc, PO Box 121, Wellington, New Zealand.

Nicol, A.M.; Kitessa, SM. 1995. Compensatory growth in cattle - revisited. Proceedings of the New Zealand Society of Animal Production 55: 157-160.

Pleasants, A.B.; Barton, R.A.; Batley, P.J. 1991. The role of beef breeding cows in strategic management of feed supply under pasture variability. Proceedings of the New Zealand Grassland Association 53: 145 149.

Pleasants, A.B.; Barton, R.A.; McCall, D.G. 1994. Nutritional buffering: Do we make the best use of this phenomena in the breeding cow. Proceedings of the New Zealand Society of Animal Production 54: 329-331.

Smeaton, D.C.; Reardon, T.F.; Nicoll, G.B.; McCall, D.G.; Welch, R.A.S. 1979. Minimum feeding requirements of beef cows. Proceedings of the Ruakura Farmers' Conference 27.

Smeaton, D.C.; Sumner, R.M.W.; Knight, T.W.; Wadams, T.K. 1983. Effects of time of weaning, pasture allowance and shearing time on ewe and lamb liveweight, wool growth and subsequent ovulation rate in ewes. New Zealand journal of experimental agriculture 11:4 1-45. 